\title{
NEW AND NOTEWORTHY NORTH AMERICAN SPECIES OF TRIFOLIUM.
}

\author{
HOMER DOLIVER HOUSE.
}

(WITH TWELVE FIGURES)

\section{NEW OR NOTEWORTHY SPECIES OF THE UNITED STATES.}

THE following notes upon the genus Trifolium are based upon material in the National Herbarium. All figures $\times \mathrm{I}_{\frac{1}{2}}$.

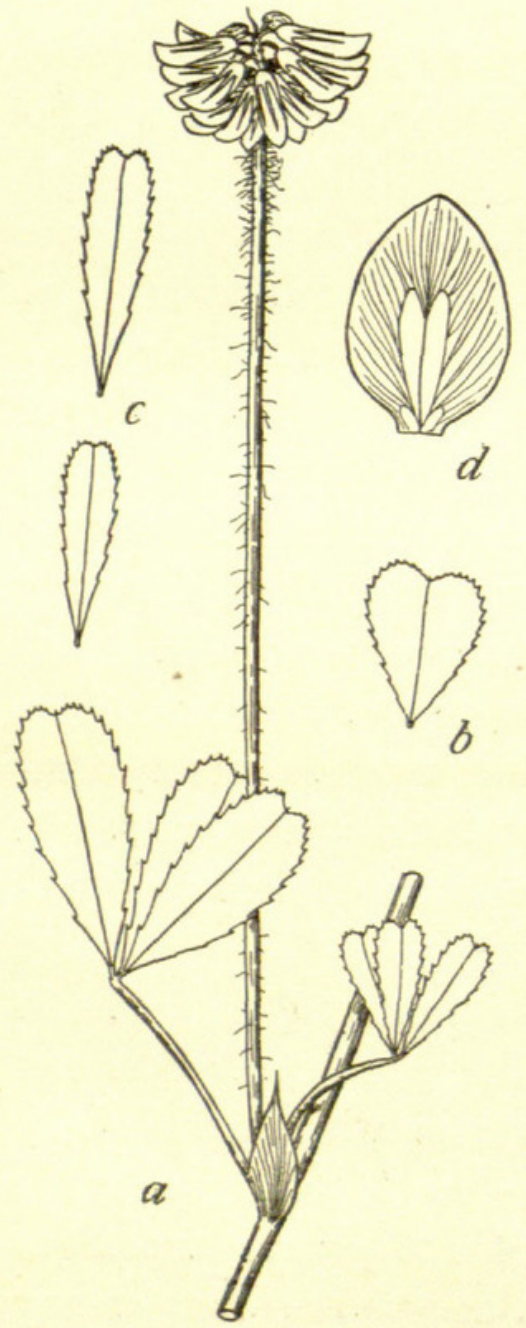

FIG. I.-Trifolium Greenei House: $a$, portion of type specimen; $b$, leaflet from lower leaf; $c$, leaflets from upper leaves; $d$, banner.

Botanical Gazette, vol. 4I]

Trifolium Greenei, nom. nov.-(Fig. I). - T. bifidum decipiens Greene, Fl. Fran. 24. I89I; not $T$. decipiens Hornem., Hort. Hafn. 2:715. I8I5.-Of much broader distribution and apparently not merging into $T$. bifidum Gray, though closely related to that species. It has more of the general appearance of $T$. gracilentum T. \& G., but distinguished from it by its villous-pubescent peduncles and cuneate-oblong, subglaucous, and retuse leaflets.

Low moist places or natural grassy meadows, from San Diego to Mendocino and Butte Counties, California. The type, collected at Berkeley by Greene, is in the herbarium of Professor Greene.

TRIFOLIUN BIFIDUM Gray (fig. 2 ) stems to be a species peculiar to the bay region of California only; the type, collected by Brewer (no. II 84, I862), "near Marsh's Ranch, between Monte Diablo and the San Joaquin (Contra Costa Co.), among grass in a ravine near the water, May 29," is in the National Herbarium.

Trifolium Breweri S. Wats., Proc. Am.Acad. II : I3I. I876.-T. amabile Loja., Nuovo Giorn. Bot. I5: I42. I883, ex descr. 
A careful reading of LoJacono's paper on North American species of Tri folium makes very apparent the fact that he had a very scanty representation of the forms and distribution of our western species. While his descriptions are
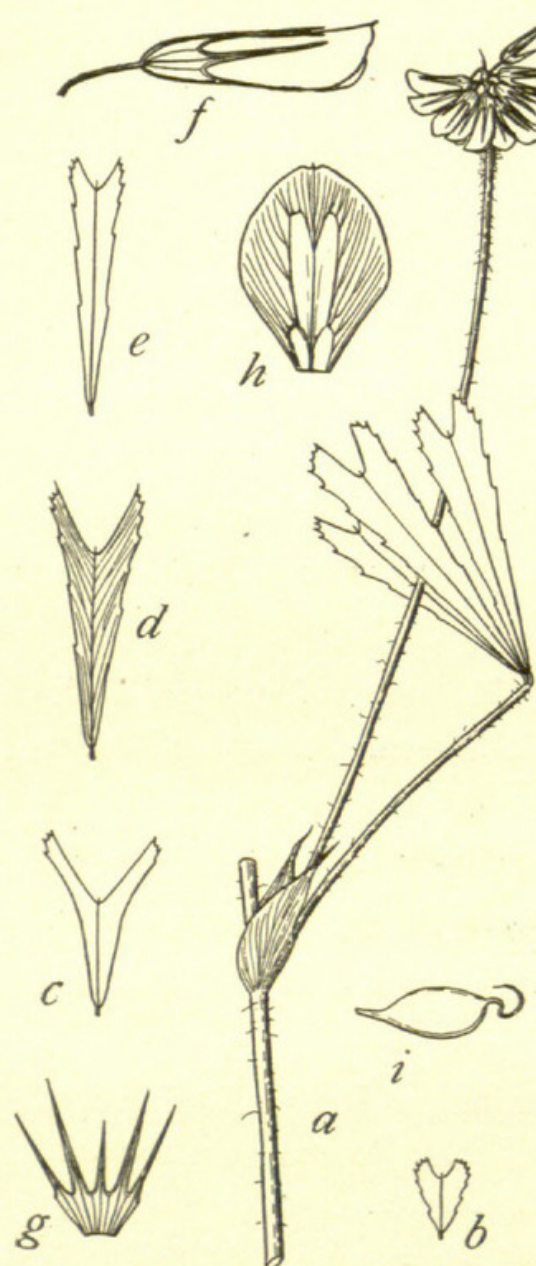

Fig. 2.-Trifolium bifidum A. Gray: $a$, portion of type specimen; $b$ and $c$, leaflets from lower leaves; $d$ and $e$, leaflets from upper leaves; $f$, flower; $g$, calyx expanded; $h$, banner; $i$, legume. excellent, he has failed in many instances to determine properly the types of the species.

Trifolium Douglasii, nom. nov.-T. altissimum Dougl., Hook. Fl. Bor.-Am. I: I30. pl. 48., I830; not T. altissimum Lois. 1807 .

An abundant clover in moist or natural wet meadows of eastern Washington, Oregon, and adjacent Idaho. Flowering in June and July, fruiting from July to the end of August.

Trifolium Harneyense Howell, Fl. Northwest Am. I34. 1898.-T. arcuatum Cusickii Piper,Bull. Torr. Bot. Club 29:642. 1902 .

An examination of the floral parts of the available herbarium material of T. Har. neyense and T. arcuatum Cusickii shows them to be identical.

\section{Trifolium villi-} ferum, sp. nov.Fig. 3.-Related to T. eriocephalum Nutt.Stems slender, erect, from perennial, ascending, and branching roots, 25 to $35^{\mathrm{cm}}$ high, densely villous-pubescent with long hairs, stem nearly glabrous at base only: leaflets oblong-lanceolate, 2.5 to $4^{\mathrm{cm}}$ long, 6 to $13^{\mathrm{mm}}$ wide, obtuse at base, usually acute at apex,

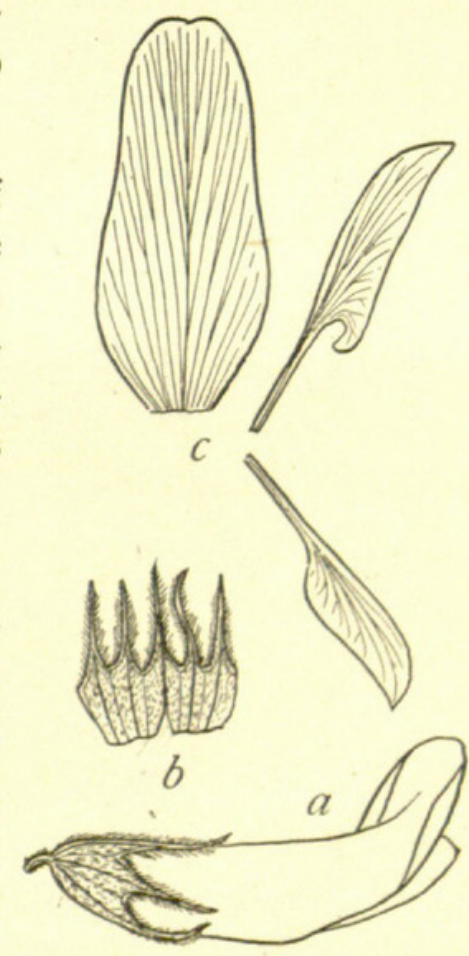

FIG. 3.-Trifolium villiferum House: $a$, flower; $b$, calyx expanded; $c$, banner, wing, and keel. irregularly and inconspicuously repand-denticulate, pale green, appearing almost glaucous by the dense, whitish indument, scarcely less 
pubescent above than below; petioles 3 to $7^{\mathrm{cm}}$ long, uppermost shortest; stipules lanceolate or the upper ovate-lanceolate, subfoliaceous, 2 to $3 \cdot 5^{\mathrm{cm}}$ long, acuminate, entire or sparingly toothed: inflorescence pseudo-terminal; peduncles 6 to $\mathrm{I}^{\mathrm{cm}}$ long; heads densely many-flowered, ovoid when young, flowers all becoming strongly reflexed: calyx densely villous with shaggy hairs without especially toward the apex, tube about $2^{\mathrm{mm}}$ long, the 5 subulate nearly equal teeth plumose, 3 to $4^{\mathrm{mm}}$ long, somewhat bent in age: corolla pinkish-purple, $\mathrm{I} 2$ to $\mathrm{I} 4^{\mathrm{mm}}$ long; banner oblong, rounded or obscurely retuse at apex, broadest (about $6^{\mathrm{mm}}$ ) below the middle; wings shorter, tapering to a blunt apex, blade with a strong basal auricle; keel still shorter and more acute: legume ovoid, sessile, densely plumose-pubescent, pubescence extending nearly to tip of style, 2 -seeded.

Flowering in June and July, fruiting in July and August. Southern Utah, Palmer (no. 9I), 1877 (type in the U. S. National Herbarium); Burrville, Sevier

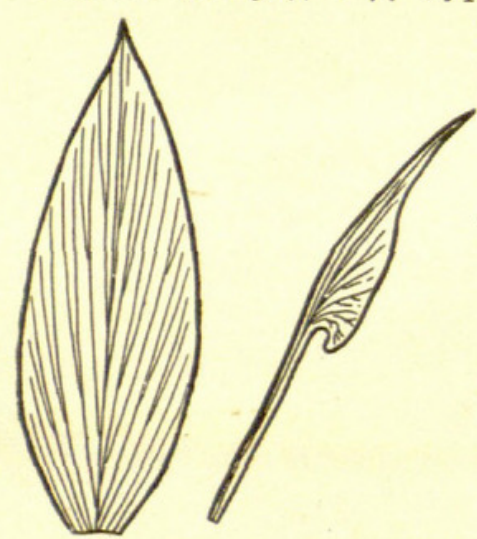
Co., Jones [(no. 5642a), July $17,1894,2100^{\mathrm{m}}$ alt.; Deep Creek, Jones, June 6, I8gr.

Trifolium atrorubens (Greene), comb. nov. -T. Rusbyi atrorubens Greene, Erythea 4:66. I896.

Type, collected by Parish (no. 3745), Buff Lake, San Bernardino Co., California, June $2 \mathrm{I}-27$, 1895 , in the herbarium of Professor Greene.

Examination of the type and several other sheets of T. atrorubens from southern California shows that it is not nearly so closely related to $T$. Rusbyi as to $T$.

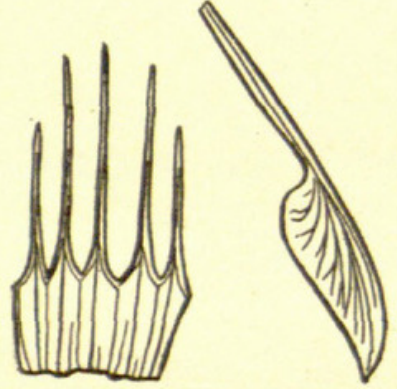

FIG. 4.-Trifolium shastense House. pedunculatum Rydb., and should properly be given specific rank.

Trifolium shastense, sp. nov.-Fig. 4.Related to T. longipes and T. oreganum. Stems numerous from matted, branching, and slender rootstocks (forming a sod), ro to $15^{\mathrm{cm}}$ high; silky pubescent above and beneath on the leaves; stems purplish below: stipules lanceolate, green, aristate-acuminate, entire or few-toothed, 12 to $20^{\mathrm{mm}}$ long; leaflets lanceolate, acute at base, often broadest above the middle, apex aristate-acuminate, margins prominently spinulose- 
denticulate, glabrous above, silky-pubescent beneath, $\mathrm{I}_{5}$ to $25^{\mathrm{mm}}$ long, 4 to $7^{\mathrm{mm}}$ wide; leaflets of the lower leaves relatively broader and shorter, nearly obovate-cuneate, acute or rounded; petioles mostly shorter than leaflets, but lower ones longer: inflorescence usually solitary; peduncles 5 to $8^{\mathrm{cm}}$ long, somewhat woolly-pubescent above with whitish hairs, densely many-flowered in a globose head; flowers sessile, the outermost spreading or becoming reflexed, Io to $3^{\mathrm{mm}}$ long: calyx silky-pubescent or becoming glabrate, tube I. 5 to $2.5^{\mathrm{mm}}$ long, the five filiform-subulate teeth straight, 8 to I0 ${ }^{\mathrm{mm}}$ long, upper ones shortest and scarcely more than $8^{\mathrm{mm}}$ long, sometimes shorter: banner sublanceolate, broadest (about $5^{\mathrm{mm}}$ ) below the middle, acuminate-pointed at the apex; wings and keel shorter, wings conspicuously attenuate-pointed, keel acute: legume stipitate, 2-seeded.

North side of Mt. Shasta, Siskiyou Co., California, ${ }_{1500-2700^{\mathrm{m}}}$ alt. Collected by H. E. Brown (no. 362), type in the U. S. National Herbarium, June II-I6, I897. No. 365 of the same collection is identieal.

Remarkable for its sharply serrated and pointed leaflets, acuminate-pointed banner, and attenuate-pointed wings.

Trifolium Covillei, sp. nov.-Fig. 5.-Related to T. latifolium. Stems very short and leafy, several from a solitary, perpendicular

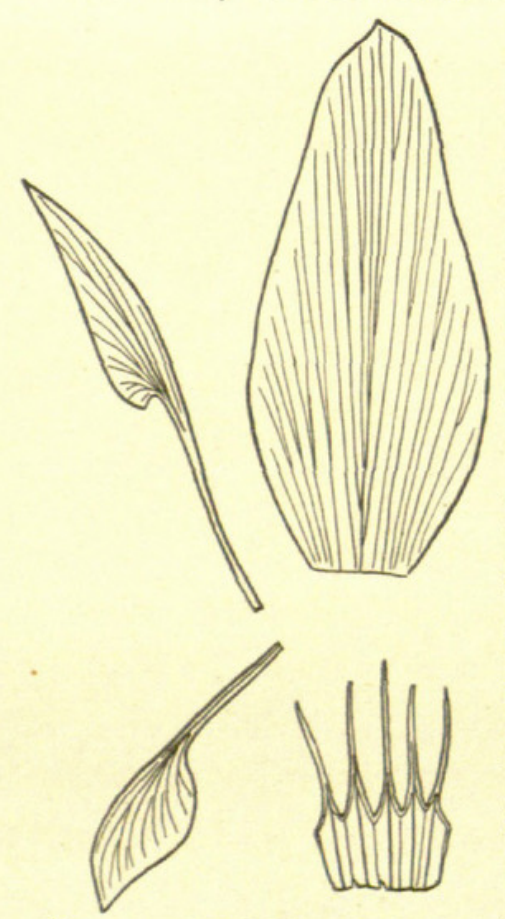

FIG. 5.-Trifolium Covillei thickened perennial root and appearing as a dense green mat at its apex, the root to to $20^{\mathrm{cm}}$ deep; stems I to $3^{\mathrm{cm}}$ long: stipules small, ovate, 5 to $7^{\mathrm{mm}}$ long, blunt and often rounded at apex, entire, adnate to the petiole for two-thirds their length; leaflets obovatesubcuneate, rounded or retuse at apex, rarely the upper acute, margins finely but not sharply or conspicuouly toothed, 6 to $\mathrm{I} 2 \mathrm{~mm}$ long, silky pubescent beneath, glabrous above; petioles mostly shorter or but little longer than the leaflets: peduncles 8 to $10^{\mathrm{cm}}$ long, much exceeding the leafy part of the plant, silky-pubescent above; heads globose, 40 to 6o-flowered, 2 to $2.5^{\mathrm{cm}}$ in diameter, some of the flowers spreading or becoming reflexed, House. 
all sub-sessile: calyx membranaceous, the tube $\mathrm{I} .5$ to $2^{\mathrm{mm}}$ long, sparingly hairy above, the 5 filiform-subulate teeth subequal, 2.5 to $3 \cdot 5^{\mathrm{mm}}$ long: banner yellowish, I2 to $\mathrm{I} 4{ }^{\mathrm{mm}}$ long, inflated and including the wings and keel, broadest ( 6 to $7^{\mathrm{mm}}$ ) below the middle, acute, wings subacuminate, keel acute: legume short-stipitate, 2 -seeded.

Bog-lands in the Wenatchee Mountains, Kittitas Co., Washington, Coville (no. Ir8o), Sept. 4, Igor (type in the U. S. National Herbarium).

The group of small species related to T. monanthum Gray has been not a little confused by various authors, and the location of the type in the U. S. National Herbarium makes it possible to define definitely its critical parts. The accompanying description and drawing are from the type.

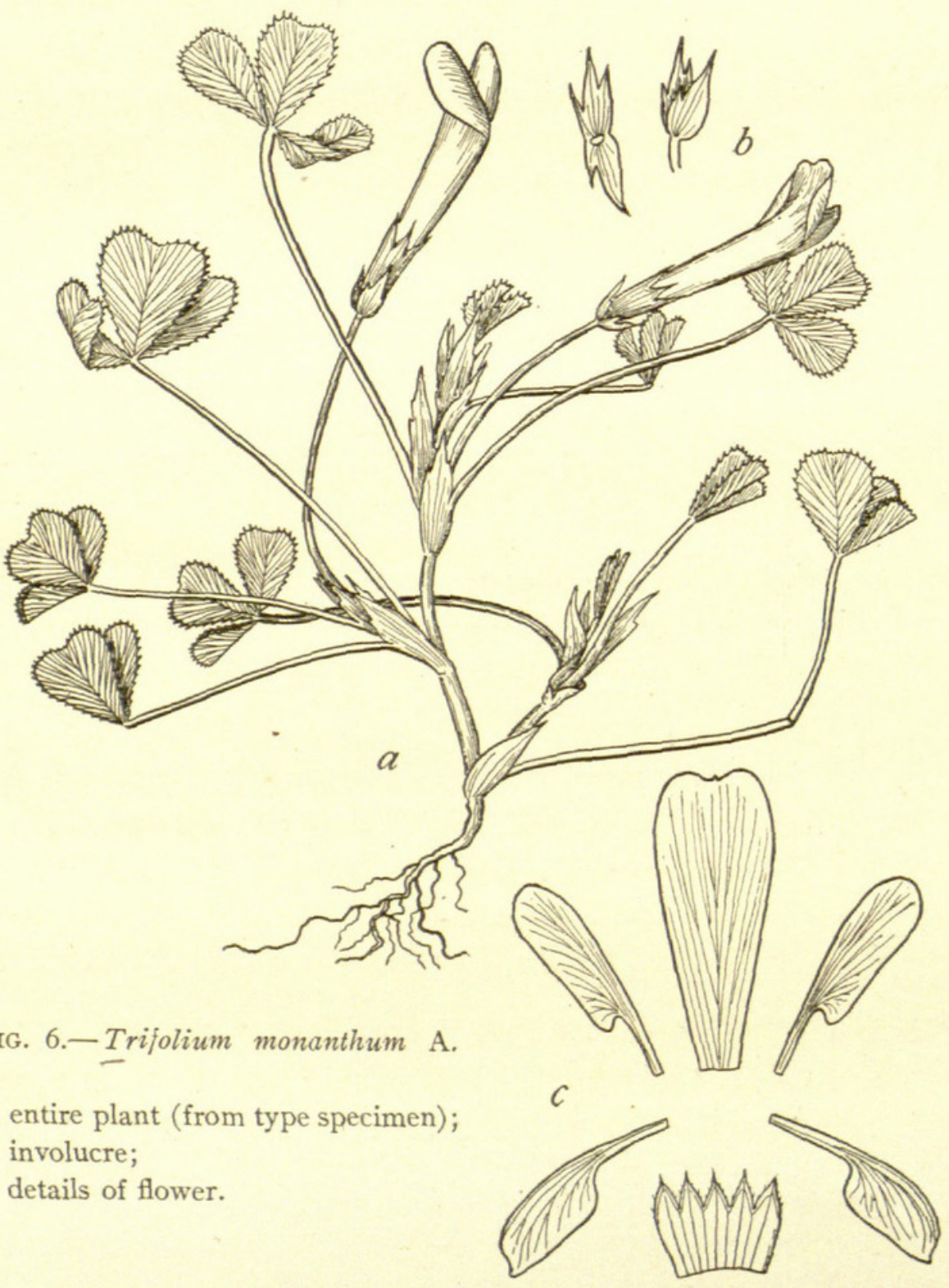
Gray:

$a$, entire plant (from type specimen);

$b$, involucre;

$c$, details of flower. 
Trifolium monanthum A. Gray, Proc. Am. Acad. 6:523. I865.-Fig. 6.-Perennial from numerous, slender, branching roots; stems branching from near the base, ascending, 2 to $4^{\mathrm{cm}}$ high, only sparingly villous: stipules ovate-lanceolate, green, 3 to 5 -nerved, cuspidate-acuminate, 2 to $4^{\mathrm{mm}}$ long, entire or rarely with a few minute rigid teeth near the apex; leaflets obovate-cuneate, retuse or truncate at apex, margins spinulose-denticulate, 4 to $6^{\mathrm{mm}}$ long, sessile, pale green with a few villous hairs beneath, darker green above, the ascending, branching whitish veins ending in the subcallous mucronate teeth of the margin; petioles filiform, longer than the leaflets: peduncles filiform, mostly shorter than the leaves, one-flowered (rarely 2), involucre of two entire or sparingly toothed, ovate-lanceolate, cuspidate-acuminate bracts, 2 to $3^{\mathrm{mm}}$ long: calyx cylindrical, twice as long as involucre, about $4^{\mathrm{mm}}$ long, sparingly villous, Io-nerved, 5 of the nerves more prominent than the others, the triangular-lanceolate, spinulose-acuminate teeth about one-third the length of the tube: corolla 9 to $\mathrm{I}^{\mathrm{mm}}$ long, purplish-white, the slender tube elongated and somewhat glandular, not scarious or inflated after flowering; banner lanceolate-obovate, retuse; wings shorter and rounded; keel sub-acute: legume stipitate, 2 -seeded.

Flowering from the middle of June to September; fruiting from July to October*

Mountain meadows, banks, and grassy places, Sierra Nevada in California from Alpine to Tulare County, and in Ormsby County, Nevada; 2100 to $3000^{\mathrm{m}}$ alt.

California: Sierra Nevada, Lemmon 1875; Manachi Meadows, $2500^{\mathrm{m}}$ alt., Rothrock (no. 307), Sept. 1875; Tuolumne Co.: "Moist bank by Soda Springs, alt. $265^{\circ \mathrm{m}}$," Brewer, June 26,1863 (no. I 704 ), type in U. S. National Herbarium; vicinity of Tuolumne Meadows, $2600-2900^{\mathrm{m}}$ alt., Hall and Babcock, July I902 (no. $3_{625}$ ); Alpine Co.: Caple's Lakes, $2600^{\mathrm{m}}$ alt., Hansen, June 21, 1892 (no. 35 I); Fresno Co.: meadows near Block mountain, $3000^{\mathrm{m}}$ alt., Hall and Chandler, July 1900 (no. 613); Tulare Co. near Mineral King, $275^{\mathrm{m}}$ alt., Coville and Funston, Aug. 4, I89r (no. 1473).

Nevada: Ormsby Co.: Snow Valley, $2460-26 \mathrm{r}^{\mathrm{m}}$ alt., C. F. Baker, July 8, 1902 (no. I282).

Trifolium tenerum Eastw., Bull. Torr. Bot. Club 29:81. IgO2. "Higher meadows on the trail to the South Fork of King's River (Fresno Co.), California. It was collected by the writer at Summit and Bearskin Meadows, July I-I3, I899. The first named speci- 
mens are considered the type specimens. Type in the Herbarium of the California Academy of Sciences."

Characterized by the canescent and softly villous foliage, strongly nerved and setosely serrulate leaflets; heads I to 6-flowered; involucre glabrous, of 2-5 separate, laciniate-aristate bracts, 2 to $4 \mathrm{~mm}$ long; banner of the corolla with three rounded teeth at the truncate apex; wings slender, as long as the banner, auriculate at base of blade; keel two-thirds as long, tipped with an obtuse erect beak, the keel itself purple, auricled at base; ovary obovate, pilose at summit, one-ovuled.

Trifolium Grantianum Heller, Muhlenbergia i: 136.

Undoubtedly distinct from $T$. tenerum Eastw., as HELLER indicates, but it is unfortunate that the floral characters were not better described ["Calyx cylindrical, or somewhat campanulate, 4 mm long, the tube $2 \mathrm{~mm}$ long, more or less membranous, veins prominent; the narrowly lanceolate teeth aristate, green: corollas $\mathrm{I}^{\mathrm{cm}}$ long, slender, $2^{\mathrm{mm}}$ across, whitish, the hood of the keel purple"] when it is considered that in this group of small species the floral characters are of the utmost importance. Calif.

Based on Grant's Number 6343, July 23, 1904, from San Bernardino Co.,

Trifolium parvum (Kellogg) Heller, Muhlenbergia I: II4. I905.-Fig. 7.-T. pauciflorum (?) var. parvum Kellogg, Proc. Cal. Acad. 5:54. I873; T. multicaule Jones, Bull. Torr. Bot. Club 9:3 I. I882.-The prostrate or slightly ascending stems Io to $20^{\mathrm{cm}}$ long, often many from a thickened root; softly silky-pubescent, sometimes densely so: leaflets obovate, retuse or obtuse or sometimes those of upper leaves short acute at apex, subcuneate at base, minutely spinulose-serrulate; stipules broadly ovate, sharply toothed and acute; petioles filiform, the lower. I to 3 times the length of the leaflets, the upper scarcely longer than the leaflets: peduncles exceeding the leaves, I to $3^{\mathrm{cm}}$ long, I to 7 (usually 2 to 5 )-flowered; involucre 5 to 7 -divided into triangular-lanceolate acute and entire segments, $\mathrm{I}$ to $2^{\mathrm{mm}}$ long, these spreading in age, rarely somewhat toothed: calyx 3 to $4^{\mathrm{mm}}$ long, villous-pubescent, the 5 triangular lanceolate teeth about equaling the tube in length, the lower one 
a little shorter and broader than the others, all spinulose-acuminate: corolla a little more than twice the length of the calyx, white with a purple-tipped keel; banner narrowly oblong, about $\mathrm{Io}^{\mathrm{mm}}$ long and 3.5 to $4.5^{\mathrm{mm}}$ wide, deeply retuse at apex; wings and keel much shorter, the keel acute: legume 2 -seeded.

Around springs and in natural moist meadows of the Sierra Nevada, California, from Nevada Co. to Acador Co., Yosemite Park, and Fresno Co., at I50o to $2100^{\mathrm{m}}$ alt.

Nevada Co.: Soda Springs, Jones (no. 2592), July 30, I88I (type of T. multicaule, in U. S. National Herbarium); low ground on south side of Donner Lake, Heller (no. 6942), July 16, 1903.

Amador Co.: Bear River, Hansen (no. I968), Aug. 30, 1896 .

Yosemite Park: Hetch-Hetchy Trail, Hall and Babcock (no. 3385), July 1902 .

Fresno Co.: Pine Ridge. Hall and Chandler (no. 256), June $15^{-25}$, 1900.

Trifolium simulans, sp. nov.-Fig. 8.-Perennial from slender, branching roots; stems numerous, prostrate or ascending, slender, 5 to $20^{\mathrm{cm}}$ long, glabrous: stipules ovate-lanceolate, 6 to $10^{\mathrm{mm}}$ long, green or the lower ones subscarious, spinulose-acuminate, and with a few aristate teeth, 5 to 7 -nerved; leaflets oblong-lanceolate, the middle one and often the others cuneate, irregularly spinulose-denticulate, mucronatetipped at the acute apex, 9 to $\mathrm{I} 4^{\mathrm{mm}}$ long, 2.5 to $5^{\mathrm{mm}}$ wide; petioles filiform, 2 to 4 times the length of the leaflets: peduncles as slender and shorter than the petioles; involucre divided into 2 or 3 parts, these cleft again to make 5 to 7 narrow, spinulose-acuminate, conspicuously nerved, simple or fewtoothed segments to the entire involucre: calyx short-pedicelled, glabrous, about twice the length of the involucre, teeth subulateacuminate, 3 to $4^{\mathrm{mm}}$ long, the lower slightly shorter: corolla very large for the size of the plant, white with a purple-tipped keel; banner narrowly oblong, about $15^{\mathrm{mm}}$ long, $5^{\mathrm{mm}}$ wide, retuse and mucronate at apex; wings

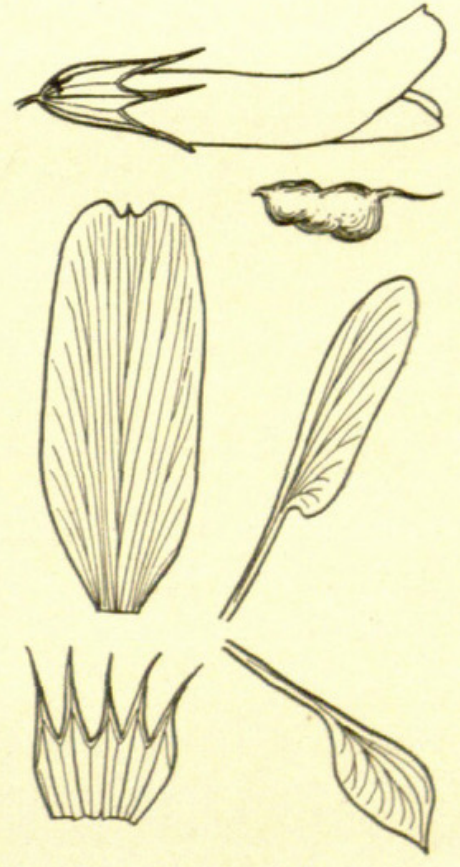

FIG. 8.-Trifolium simulans House. 
and keel much shorter, blade of wings about $9^{\mathrm{mm}}$ long, that of the acute keel only about $4^{\mathrm{mm}}$ long: legume 2 -seeded, sessile.

San Jacinto Mountains, California, 1800 to $2700^{\mathrm{m}}$ alt., H. M. Hall (no. 710), July 22, I897, type in the U. S. National Herbarium); Strawberry Creek (San Jacinto.Mts.) ' $1600^{\mathrm{m}}$ alt., H. M. Hall (no. 2200), June 20, rgor.

Resembling $T$. parvum in size, but very distinct from it in the remarkably large flowers for the size of the plant, the leaf, calyx, and corolla characters also showing well-marked differences. It appears to be as distinct from $T$. parvum as $T$. tenerum is from $T$. monanthum, and to show these differences descriptions of all three species are given.

\section{MEXICAN SPECIES.}

Trifolium amabile HBK., Nov. Sp. \& Gen. 6:503. pl. 593. I823; T. Humboldtii Spreng., Syst. 3:3I3. I826 (T. pauciflorum Willd. herb.); T. Hemsleyi Loja., Nuovo Giorn. Bot. I5: I43. pl. 4 . fig. I. 1883 .

One of the commonest species of Mexico and distributed from northern Mexico to Central America.

Trifolium gracilentum T. \& G., Fl. N. Am. I:3i6. I838; T. denudatum Nutt., Proc. Acad. Phila. II. I:I52. I848.

Lower California, San Quentin Bay, Palmer (no. 613), Jan. I889.

Trifolium longifolium (Hemsley), comb. nov. $-T$. amabile var. longifolium Hemsley, Biol. Cent. Am. Bot. I:232.I879; T. goniocarpum Loja., Nuovo Giorn. Bot. I5:I45. pl. 4. fig. 2. I883.

Hemslex's description is based upon Parry and Palmer's no. I34, although other specimens are mentioned. Lojacono's description is also based upon a plant collected by Parry and Palmer, but no collection number is given. His description, however, agrees well with a duplicate of HEMSLEY's type in the National Herbarium, and the conclusion was forced upon me that they are identical.

San Luis Potosi, Parry and Palmer (no. 134), 1878: Chihuahua, Pringle (no. 1208), 1887; Townsend and Barber (no. 177), 1899; Palmer (no. 385), 1885: Durango, Palmer (no. 237), 1896: Tepic, Rose, Aug. 9, 1897: Jalisco, Palmer (no. 236), 1886: Aguascalientes, Rose and Painter (no. 7795), 1903: Federal Dist., Pringle (no. 7492), I897: Vera Cruz, Orizaba, Bourgeau, 1865-66; Seaton (no. 93), r89r: Oaxaca, Rose and Hough (no. 4644), r899.

Trifolium Lozani, sp. nov.-Fig. 9.--Related to T. mexicamum. Stems numerous, spreading and ascending from a perennial root densely silky-pubescent, ro to $20^{\mathrm{cm}}$ long; the internodes relatively 
short: stipules ovate, lower scarious and entire, upper green and sparingly toothed, all acuminate, 6 to $10^{\mathrm{mm}}$ long, 4 to $6^{\mathrm{mm}}$ wide; leaflets cuneate-obovate or cuneate-oblong, sessile, 8 to $15^{\mathrm{mm}}$ long, 5 to $10^{\mathrm{mm}}$ wide, rounded at apex, glabrous above, sparingly pubescent beneath, subentire, the minute teeth very inconspicuous; petioles mostly shorter than the leaflets, or the lower slightly longer: peduncles scarcely exceeding the leaves, I to $3^{\mathrm{cm}}$ long; heads globose, ebracteate, 25 to 50 -flowered; flowers short-pedicelled, all becoming reflexed: calyx tube subcampanulate, pubescent, slightly more than $\mathrm{I}^{\mathrm{mm}}$ long; the subulate teeth twice as long, four of them ascending, lower one straight: corolla yellowish; banner broadly oblong, $5^{\mathrm{mm}}$ long or less, retuse; wings and keel much shorter, subacute: legume oblong in outline, very blunt at apex, $3^{\mathrm{mm}}$ long or

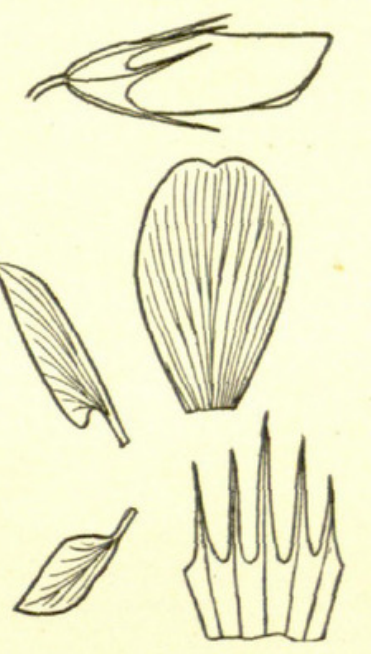

FIG. 9.-Trifolium Loani House.

less, 4-seeded: seeds nearly as thick and broad as long, smooth and
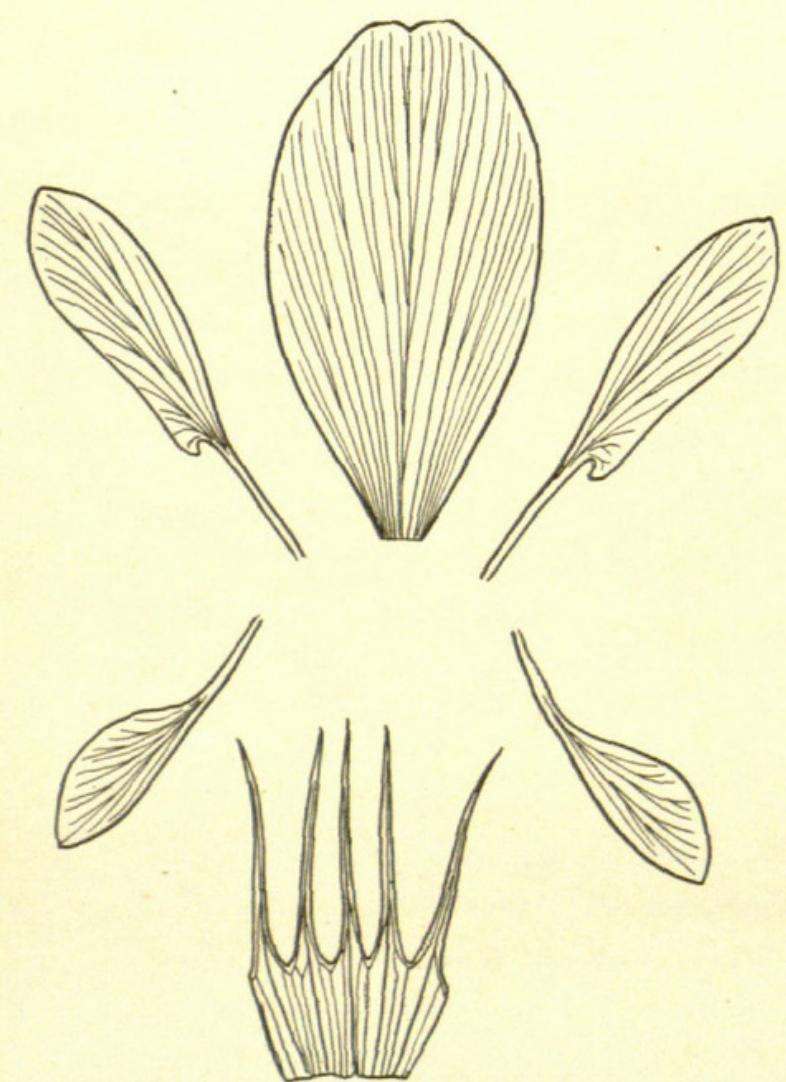

FIG. ro.-Trifolium mexicanum Hemsley. brownish, less than $\mathrm{I}^{\mathrm{mm}}$ long.

Eslava, Federal District, $2300^{\mathrm{m}}$ alt., Pringle (no. 9512), June $\mathrm{I}_{5}$, I90 (type sheet no. 396298 in U. S. National Herbarium). Distributed as T. amabile, which it in no way resembles. It differs from $T$. mexicanum by its more densely pubescent stems and pedun. cles, smaller flowers, and relatively shorter calyx teeth. Named in honor of Señor Filemon Lozano, assistant to Mr. Pringle.

\section{Trifolium Mexicanum Hems-} ley, Biol. Centr. Am. Bot. I: 233 . I879.-Fig. Io.-T. potosanum Loja., Nuovo. Giorn. Bot. I5: I44. pl. 2. 1883.

The type of $T$. mexicanum is from San Luis Potosi (Parry and Palmer no. I37, 1878 ), and upon the same number 
is based $T$. potosanum Loja. A duplicate type is in the U. S. National Herbarium.

The following specimens from central Mexico differ from typical $T$. mexicanum in having larger flowers, more pubescent stems, and blunter leaflets, and are more spreading in habit. They may represent a variety, but scarcely more.

Mexico (state): hills near Ozumba, $2400^{\mathrm{m}}$ alt., Pringle (no. 9775), Nov. 8, I902; Flor de Maria, Pringle (no. 3238), Sept. 4, I89o; Rose and Painter (no. 7816), Oct. I3, I903.

Trifolium Nelsoni, sp. nov.-Fig. I .-Related somewhat to T. mexicanum but scarcely resembling it. Stems spreading and
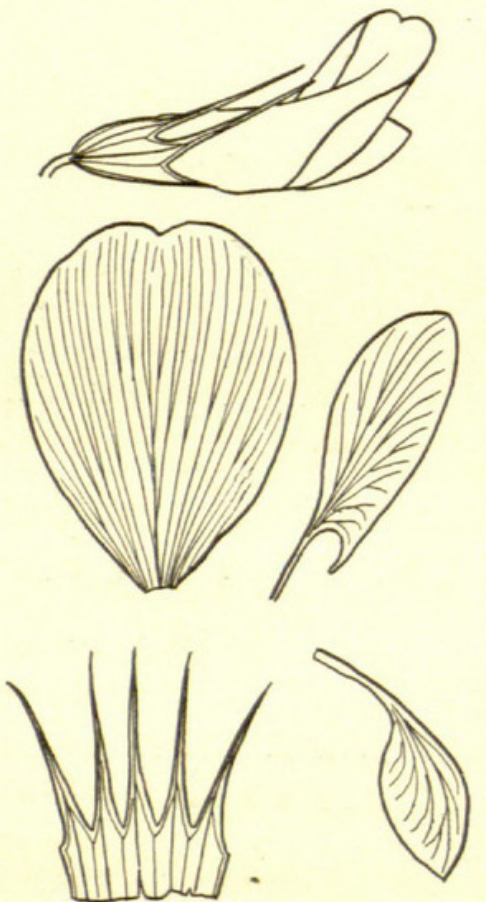

FIG. II.-Trifolium Nelsoni House. ascending from a perennial root, minutely pubescent, about $50^{\mathrm{cm}}$ long or less: stipules ovate-lanceolate, green, rigid and the lower scarious, aristate-acuminate, entire, $\mathrm{I}_{5}$ to $20^{\mathrm{mm}}$ long; leaflets ovatelanceolate to elliptic-oblong, sparingly pubescent and pale beneath, green and glabrous above, usually with a whitish V-shaped blotch on the upper surface, apex acute or blunt, callous-tipped, margins inconspicuously repand-denticulate; petioles of the lower leaves 2 to 4 times the length of the leaflets: peduncles densely woolly-pubescent toward the summit, often $\mathrm{I} 5$ to $20^{\mathrm{cm}}$ long; heads depressedglobose, 20 to 40 -flowered, flowers subtended by subulate filiform bracts, 3 to $5^{\mathrm{mm}}$ long; pedicels none or very short: calyx-tube io-nerved, about $\mathrm{I} \cdot 5^{\mathrm{mm}}$ long, the subulate green teeth 4.5 to $5^{\mathrm{mm}}$ long, subequal: corolla yellowish; banner 8 to I $^{\mathrm{mm}}$ long, orbicular-obovate, slightly retuse at the apex or rounded; wings and keel shorter but relatively broad.

Vicinity of La Parada, Oaxaca, E.W. Nelson (no. Ior6), Aug. 19, I894 (type in the U. S. National Herbarium). Remarkable for the extremely broad petals.

Trifolium Palmeri S. Wats., Proc. Am. Acad. ir:I32. I876.

Guadalupe Island: Palmer (no. 26, I875), type in Gray Herbarium; a duplicate type in herbaria of Professor Greene and Columbia University; Greene Apr. 21, 1885; Palmer (no. 859), 1889; Dr. F. Franceschi, 1893. 
Trifolium cognatum, sp. nov.-Fig. I2.-Related to T. longifolium. Minutely pubescent or glabrate; stems spreading or ascending from a thickened perennial root, Io to $30^{\mathrm{cm}}$ high, often somewhat tinged with dull purple below, striate: stipules ovate or the lower ovate-lanceolate, green, acuminate, entire and scarious margined, $\mathrm{I} 2$ to $\mathrm{I} 6^{\mathrm{mm}}$ long; leaflets elliptical-oblong, subcuneate at base, glabrous, rounded and minutely mucronate at apex, 8 to $20^{\mathrm{mm}}$ long, 4 to Io $^{\mathrm{mm}}$ wide, margins minutely and irregularly denticulate; petioles 2 to 4 times as long as the leaflets: peduncles exceeding the leaves; heads subglobose, I 5 to 40 -flowered; flowers erect when young, soon becoming entirely reflexed, their pedicels
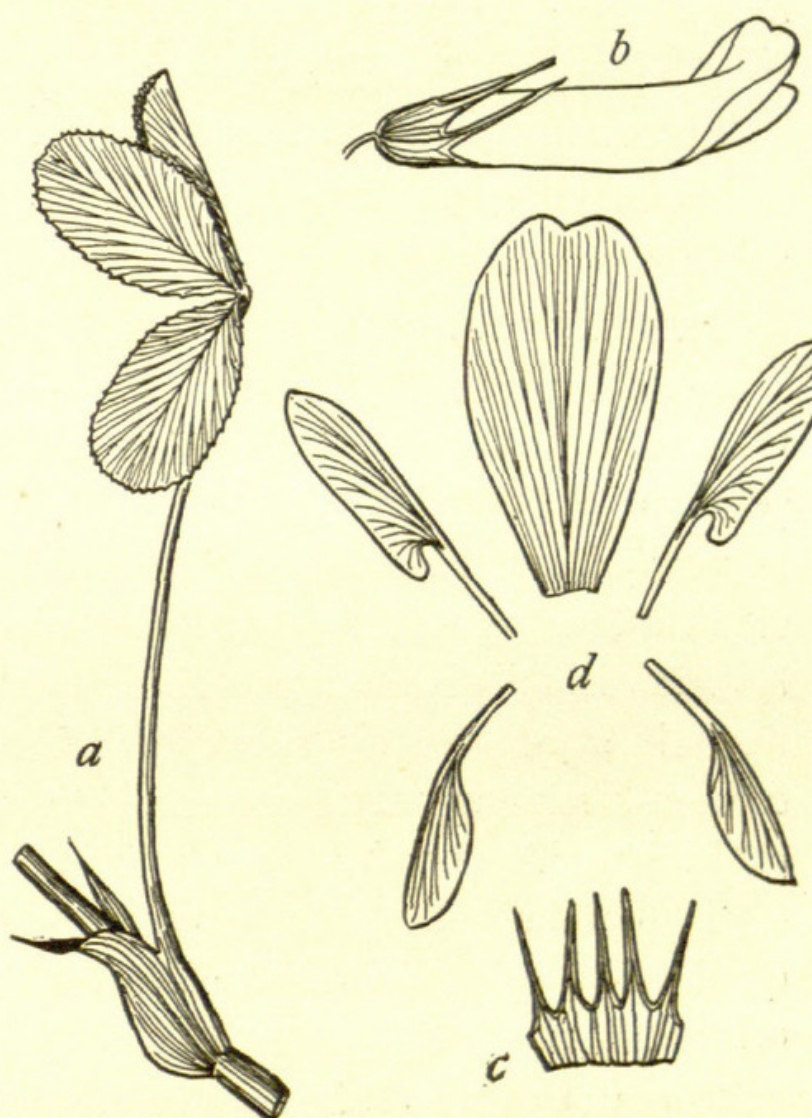

FIG. 12.-Trifolium cognatum House: $a$, stipule and leaflets; $\vec{b}$, flower; $c$, calyx expanded; $d$, banner, wings, and keel.

2 to $4^{\mathrm{mm}}$ long: calyx with a few scattered hairs, the tube ro-nerved, about $\mathrm{I}^{\mathrm{mm}}$ long, the subequal, subulate-acuminate teeth 3 to $3 \cdot 5^{\mathrm{mm}}$ long: corolla 7 to $9^{\mathrm{mm}}$ long; banner violet-purple, ascending, retuse at apex, nearly $5^{\mathrm{mm}}$ broad; wings and keel shorter and yellowish: legume 3 or 4 -seeded.

Barren hills above Pachuca, Hidalgo, $2600-2900^{\mathrm{m}}$ alt., Pringle (no. 6933), July 30 , 1898. Type in U. S. National Herbarium.

Although fully matured legumes are not present on the type, the species is evidently related to $T$. longifolium (T. goniocarpum Loja.), from which it is distinguished by its larger flowers, slight pubescence, rounded or blunter leaflets, and more slender ovary. Peculiar in the purplish banner and yellowish wings and keel, the reverse of the condition of coloring usually seen in clovers with purple and yellow flowers. 
Trifolium Repens L., Sp. Pl. 767. I753.

Reported by authors from the valley of Mexico and specimens from Central America have been examined. Probably introduced and escaped about many of the larger cities and seaports.

Trifolium microcephalum Pursh, Fl. Am. Sept. 2:478. i8i4.

Guadalupe Island, Palmer (no. 83r), Apr. I, i88g. Probably also occurring in northern Lower California.

Trifolium Rhombeum S. Schauer, Linnaea 20:740. I847.

As I have not been able to establish fully the identity of this species, further than to advance the suggestion that it is perhaps the $T$. mexicanum of Hemsley, the original description is given here in full.

"Trifolium (Trifoliastrum) rhombeum S. Schauer: caulibus adscendentibus striatis cum petiolis pedunculis calycibusque villosolanuginosis, foliolis rhombeo-ellipticis obtusis mucronatis arguta denticulatis striato-venosis supra glabris subtus pilosiusculis glabrescentibus, stipulis membranaceis lato-ovatis mucronulatis pilosulis, capitulis axillaribus longe pedunculatis multifloris densis exinvolucratis, floribus pedicellatis demumque deflexis, calycis laciniis subaequalibus setaceis erectis tubo brevi longioribus corolla tertia brevioribus glabris.

"In montosis Mexici. Aschenb. n. I64. (perennial).

"Ex typo Tr. hybridi nostratis; inter mexicana forte affine Tr. amabili HBK., ceterum pubescentia, foliorum figura et serratura floribusque magnis insignis. Petioli 6-9 lin. longi, stipulis duplo longiores; foliola subpollicaria. Pedunculi folium longe excedentes. Flores magni, yexillo 4 lin. aequante Corolla alba vel pallide rosea ex sicco videtur, vexillum emarginatum."

Trifolium Schiedeanum S. Wats., Proc. Am. Acad. 17:338. I883. $-T$. reflexum Schlecht., Linnaea 5:576. I830; not L.

"Jalapa (Schiede), and at Lerios, 45 miles east of Saltillo, [E. Palmer] (20I)."

The locality for Schiede's plant as given by SCHLeChTENDAL is "Prope Jalapan ad latera montis Macultepec, San Andres inque graminosis."

A duplicate of Palmer's plant mentioned above is in U. S. Nat. Herbarium.

Trifolium tridentatum Lindl., Bot. Reg. sub pl. I070. I827.

Lower California, Todos Santos Island, Anthony (no. 194), I897; San Quentin Bay, Palmer (no. 697), 1889.

Trifolium Willdenovir Spreng., Syst. 3:208. I826.-T. involucratum Orteg., Hort. Matr. Dec. 33. I797; Willd., Sp. Pl. 3:1372. 
I80 ; not T. involucratum Lam. I778; T. Ortegae Greene, Pittonia 3: 186. I 897 .

Both Wilidenow and SPREngel seem uncertain regarding the native country of this species and the identification of Willdenow's name with an American species is perhaps first made by HBK. (Nov. Gen. \& Sp. 6:502. 1823): "Crescit prope Valladolid Mexicanorum alt. Iooo hex."

This species, not rare throughout northern Mexico, is not at all closely related to the species of California which for so long has passed as $T$. involucratum and which Professor Greene has shown to be T. Wormskioldii Lehm.

The important characters of $T$. Willdenovii are the linear-lanceolate stipules, subulate-acuminate and lacerate-toothed; the involucre divided nearly to the base into 6 to 8 nearly simple, subulate-aristate segments, resembling in this respect the T. spinulosum of northwestern United States, but not T. Wormskjoldii of California. The leaflets are all linear and apiculate, except those of the lower leaves which are relatively broader; the purple flowers are from $\mathrm{I} 6$ to $18^{\mathrm{mm}}$ long, in large erect heads; the banner very narrow and retuse at apex.

Chihuahua: Nelson (no. 6054), 1899; Townsend and Barber (no. 60), 1899, Goldman (no. 430), 1899; Palmer (no. 309), I885; Pringle (no. Ј209), i887.

Durango: Palmer (no. 238), I896; Nelson (no. 4768), 1898.

San Luis Potosi: Parry and Palmer (no. 135), 1878; Schaffiner (no. 602), I879.

Valley of Mexico: Bourgeau (no. 79), I865-66; Pedregal, near Tlalpam, Rose and Hough (no. 45 I8), I899.

Clemson College, South Carolina. 


\section{$2 \mathrm{BHL}$ Biodiversity Heritage Library}

House, Homer D. 1906. "New and Noteworthy North American Species of Trifolium." Botanical gazette 41(5), 334-347. https://doi.org/10.1086/328826.

View This Item Online: $\underline{\text { https://www.biodiversitylibrary.org/item/94872 }}$

DOI: https://doi.org/10.1086/328826

Permalink: https://www.biodiversitylibrary.org/partpdf/223223

\section{Holding Institution}

Missouri Botanical Garden, Peter H. Raven Library

\section{Sponsored by}

Missouri Botanical Garden

\section{Copyright \& Reuse}

Copyright Status: Public domain. The BHL considers that this work is no longer under copyright protection.

This document was created from content at the Biodiversity Heritage Library, the world's largest open access digital library for biodiversity literature and archives. Visit BHL at https://www.biodiversitylibrary.org. 